\title{
State Production Taxes and The Commerce Clause
}

I $\mathrm{N}$ law, if not in mathematics, things which are equal to the same thing are not always equal to each other-which shows that in law there is more of human fallibility and human fiat than in mathematics. Judges are not always persuaded that a rose by any other name would smell as sweet, and their noses are sometimes led by names rather than by substance. Several instances of this appear in the nolos and volos which dictate the decisions on state taxation of interstate commerce. The professed principle that a state may not by taxation burden interstate commerce turns out upon analysis to be merely a doctrine that a state may not tax interstate commerce "as such"; and the suchness vel non of what is being taxed seems sometimes to be determined by norms of nomenclature rather than of economic effect. Thus we find that here and there a state may in one way reap the same revenue and impose the same burden on interstate commerce that in other ways are forbidden.

Signs of such a contrast are seen in two recent decisions allowing the states to impose production taxes although the products are immediately sent to other states. While it is established that a state may not impose a property tax on goods in actual course of interstate transit, ${ }^{1}$ Heisler v. Thomas Colliery $\mathrm{Co}^{2}$ sustains a Pennsylvania tax of one and one-half per cent. upon the value of anthracite coal when prepared for the market, although eighty per cent. of Pennsylvania anthracite goes to other states which must look to Pennsylvania for almost their entire source of supply. So also, while it is well settled that a state may not tax the $a^{3} t^{3}$ or the occupation ${ }^{4}$ of interstate transportation or the gross receipts derived therefrom ${ }_{2}^{5}$

1 Kelley v. Rhoads (1903) 188 U. S. 1, 47 L. Ed. 359, 23 Sup. Ct. Rep. 359; Champlain Realty Co. v. Brattleboro (1922) 260 U. S. -, 67 L. Ed. 43 Sup. Ct. Rep. 146.

2 (1922) 260 U. S. -, 67 L. Ed. -, 43 Sup. Ct. Rep. 83.

3 Passenger Cases (1849) 48 U. S. (7 How.) 283, 12 L. Ed. 702; Case of the State Freight Tax (1873) 82 U. S. (15 Wall.) 232, 21 L. Ed. 146; Telegraph Co. v. Texas (1882) 105 U. S. 460, 26 L. Ed. 1067; Eureka Pipe Line Co. v. Hallanan (1921) 257 U. S. 265,66 L. Ed. 227, 42 Sup. Ct. Rep. 101 ; United Fuel Gas Co. v. Hallanan (1921) 257 U. S. 277, 66 L. Ed. 234, 42 Sup. Ct. Rep. 105.

4 Gloucester Ferry Co. v. Pennsylvania (1885) 114 U. S. 196, 29 L. Ed. 158, 5 Sup. Ct. Rep. 826; Leloup v. Port of Mobile (1888) 127 U. S. 640, 32 L. Ed. 311, 8 Sup. Ct. Rep. 1383.

5 Philadelphia \& Southern Steamship Co. v. Pennsylvania (1887) 122 U. S. 326, 30 L. Ed. 1200, 7 Sup. Ct. Rep. 1118; Galveston, Harrisburg etc. 
Oliver Mining Co. v. Lord ${ }^{6}$ sanctions a Minnesota occupation tax on mining or producing ores within the state, although practically all of the ore of the complaining producer was mined to fulfill existing contracts with dealers or consumers in other states and the demand for ore in the taxing state covers only a negligible percentage of that mined therein. Obviously the Pennsylvania property tax on coal ready for shipment and the Minnesota excise on the occupation of mining ore are paid ultimately almost wholly by consumers in other states, and the burden on them is economically as direct and as inevitable as though the taxes were on the coal while in the course of interstate shipment or on the transportation of the ore rather than on its extraction. Significantly, also, these two taxes were not general taxes on all products or occupations within the taxing state but were special taxes on a selected product and a selected occupation which were of special concern to consumers in other states. Notwithstanding this peculiar element in the situations, the Supreme Court unanimously followed prior rulings that production is not commerce $^{\tau}$ and that goods are not articles of interstate commerce until in actual course of interstate transit. ${ }^{8}$ Thus the states which are rich in natural resources may exact tribute from their lessfavored neighbors, although one of the chief inducements of the commerce clause, as indeed of the Constitution itself, was the desire to prevent the coastal states from taking advantage of their fortunate location to levy tribute on their inland neighbors.

The approval of such production taxes would be substantially absurd if the doctrine that the states may not tax interstate commerce establishes a wise policy which should be pursued through thick and thin. Examination reveals, however, that this doctrine is doctrine only and not an unqualified pragmatic rule. Notwithstanding the doctrine, the decisions show that the states may tax interstate commerce, provided they do it in approved ways. They may tax property used for interstate commerce and assess it at a capitalization of the profitability of that commerce. They may tax net

Ry. Co. v. Texas (1908) 210 U. S. 217, 52 L. Ed. 1031, 28 Sup. Ct. Rep. 638; Oklahoma v. Wells, Fargo \& Co. (1912) 223 U. S. 298; 56 L. Ed. 445; 32 Sup. Ct. Rep. 328.

6 (1923) 262 U. S. - 67 L. Ed. -, 43 Sup. Ct. Rep. 526.

7 The leading case is Kidd v. Pearson (1888) 128 U. S. 1, 32 L. Ed. 346, 9 Sup. Ct. Rep. 6.

8 The leading case is Coe v. Errol (1886) 116 U. S. 517, 29 L. Ed. 715, 6 Sup. Ct. Rep. 475.

9 Adams Express Co. v. Ohio State Auditor (1897) 166 U. S. 185, 41 L. Ed. 965, 17 Sup. Ct. Rep. 604; St. Louis etc. Railway Co. v. Missouri (1921) 256 U. S. 314, 65 L. Ed. 946, 41 Sup. Ct. Rep. 488. 
income from interstate commerce ${ }^{\mathrm{I0}}$ and even gross receipts, when the gross-receipts tax is a fair substitute for a property tax.11 The enjoyment of such powers makes us shift the charge of absurdity from the decisions sanctioning production taxes to the opinions declaring that the states may not burden interstate commerce. These opinions must be taken in some Pickwickian sense. Our perplexity can be resolved only by looking through Supreme Court doctrine to the practicalities of the Supreme Court adjustments. By this enterprise of perspicacity we discover that the permitted tax burdens on interstate commerce have been ones imposed widely on business and commerce generally, while the forbidden exactions have usually been special excises on selected enterprises. General property taxes and net-income taxes afford safeguards against taxing interstate commerce more heavily than local commerce. Special excises do not. The Supreme Court's prohibitions have been directed mainly against possible discrimination against interstate commerce. The wisdom of this line of demarcation is undeniable. If a state were forbidden to reap any revenue from interstate commerce, it would in substance be required to have a protective tariff on local commerce in favor of interstate commerce. On the other hand, if allowed free rein in picking particular enterprises for special taxes, it would have a ready device for imposing a protective tariff on interstate commerce in favor of local commerce.

This brings us to the inquiry whether particular property taxes or occupation taxes imposing discriminatory burdens on selected products originating chiefly in the taxing state and consumed chiefly in other states do not have an effect on interstate commerce as undesirable as that of the special transportation taxes that have been declared obnoxious to the commerce clause. If such effect appears, it should not be difficult to spin the necessary reasoning to brand it unconstitutional. If these coal and iron taxes substantially discriminate against interstate commerce, they cannot be saved from condemnation because the enterprises on which they immediately impinge are technically not interstate commerce or not commerce at

10 United States Glue Co. v. Oak Creek (1918) 247 U. S. 321, 62 L. Ed. 1135, 38 Sup. Ct. Rep. 499 ; Shaffer v. Carter (1920) 252 U. S. 37, 64 L. Ed. 445. 40 Sup. Ct. Rep. 221; Underwood Typewriter Co. v. Chamberlain (1920) 254 U. S. 113, 65 L. Ed. 165, 41 Sup. Ct. Rep. 45.

11 United States Express Co. v. Minnesota (1912) 223 U. S. 335, 56 L. Ed. 459, 32 Sup. Ct. Rep. 328; Cudahy Packing Co. v. Minnesota (1918) 246 U. S. 450, 62 L. Ed. 827, 38 Sup. Ct. Rep. 373; Pullman Co. v. Richardson (1923) 261 U. S.,- 67 L. Ed. -, 43 Sup. Ct. Rep. 366. 
all. Neither by property taxes ${ }^{12}$ nor by occupation or sales taxes ${ }^{13}$ may a state discriminate against articles of extra-state origin. Such attempted discrimination is judicially thwarted even though the taxes are levied only on property or sales of property that has ended its interstate transit and has become subject to the general power of the state. It should not matter that these precedents involve unconstitutional discriminations by the state of destination, since in general the state of origin is as impotent to regulate interstate commerce as is the state of destination. The state of origin has found the commerce clause a barrier to transportation taxes, ${ }^{14}$ to sales taxes ${ }^{15}$ and to police regulation. ${ }^{16}$ The essence of the evil in all such invalid state action is that it reaches in part beyond the state's borders and annoys or injures extra-state interests. Some undue extraterritorial economic effect can be found in nearly every state law declared unconstitutional under the commerce clause. Such effect is thought undue when the state of destination confines its tax to articles that have come in from other states. It seems equally undue when the state of origin confines its tax to articles destined for other states. No state would be likely to impose such a tax unless assured that it could still retain its extra-state markets. Such assurance, however, is at hand when such an indispensable commodity as anthracite is found almost exclusively in a single state. If, therefore, a state of origin should conceive it profitable to tax coal mined for extra-state use and to exempt coal mined for home consumption, it seems clear that wisdom should require the discrimination to be held unconstitutional and that reason would justify reliance, on the precedents forbidding a state to tax goods brought

12 Darnell \& Son v. Memphis (1908) 208 U. S. 113, 52 L. Ed. 413, 28 Sup. Ct. Rep. 247.

13 Welton v. the State of Missouri (1875) 91 U. S. 275, 23 L. Ed. 347; Bethlehem Motors Corporation v. Flynt (1921) 256 U. S. 421, 65 L. Ed. 1029, 41 Sup. Ct. Rep. 571 .

14 Eureka Pipe Line Co. v. Hallanan, supra, note 3. No distinction is ever made between transportation to or through the taxing state and transportation from the taxing state.

15 Heyman v. Hayes (1915) 236 U. S. 178, 59 L. Ed. 527, 35 Sup. Ct. Rep. 403.

${ }_{10}$ Among many cases special attention belongs to Dahnke-Walker Milling Co. v. Bondurant (1921) 257 U. S. 282, 66 L. Ed. 239, 42 Sup. Ct. Rep. 106, and Lemke v. Farmers' Grain Co. (1922) 258 U. S. 50,66 L. Ed. 458, 42 Sup. Ct. Rep. 244, because in both these cases the sales held immune from state regulation were technically intra-state sales completed by delivery within the state and the Supreme Court granted relief under the commerce clause because in the one case the delivery was to a carrier for shipment without the state and in the other the sale was to an elevator company which habitually shipped all grain received by it to consignees in other states. 
in from outside when it exempts similar home-made articles ${ }^{17}$ and the precedents forbidding conservation legislation which grants a preference to home consumption. ${ }^{18}$

Full recognition of the unconstitutionality of formal discrimination to favor or promote local consumption to the necessary diminution of extra-state consumption does not, however, solve the issue before us. The complaint against Pennsylvania and Minnesota was that the relatively small proportion of local consumption made their taxes fall preponderantly on extra-state consumption. No sanction for such taxation should be conclusively inferred from a Supreme Court ruling that a sales tax in a consuming state does not discriminate against interstate commerce merely because the consuming state does not produce the commodity or any available substitute. ${ }^{19}$ The burden of such a tax falls on dwellers in the consuming state, and its lack of charity begins and largely ends at hoine. When the situation is reversed and a state by imposing a tax on a selected enterprise reaps a revenue from citizens of other states and imposes no corresponding burden on its own citizens, the rapacity of the taxing state has no political or economic limits other than a cautious instinct not to kill or maim the goose that lays the golden eggs. If the vitality of the goose is assured by the strength of the demand for the tax-burdened commodity there may be wisdom in a judicial curb on such fiscal designs on outsiders even though there is no need to restrain a state from burdening consumers that dwell therein. Widespread feeling on such a matter is reflected in the appearance of the attorneys general of nine states to protest against the Pennsylvania coal tax as a regulation of interstate commerce. The substantial reasons in support of their contention are not fully refuted by Mr. Justice McKenna's imaginings of the results to which its acceptance would lead. ${ }^{20}$ Nor would it do to say that, since by

17 See cases cited in notes 12 and 13 supra and in Hall, Cases on Constitutional Law, 1086, note 1 .

18 Oklahoma v. Kansas Natural Gas Co. (1911) 221 U. S. 229, 55 L. Ed. 716, 31 Sup. Ct. Rep. 564; Pennsylvania v. West Virginia (1923) 262 U. S. 67 L. Ed. - 43 Sup. Ct. Rep. 658 . Cases in which states have been allowed to forbid water and game from being sent outside the state have been rested on special grounds of unqualified power to control the antecedent diversion or reduction to possession. Yet in the Natural Gas Case the court declined to find a justification for the Oklahoma statute in the power of the state to withhold the privilege of taking property by eminent domain or the privilege of laying pipes along or across the public highways.

19 Askren v. Continental Oil Co. (1920) 252 U. S. 444, 64 L. Ed. 654, 40 Sup. Ct. Rep. 355. For a suggestion that the small amount of production in the taxing state might under some circumstances be significant see Ward v. Maryland (1871) 79 U. S. (12 Wall.) 418, 429, 20 L. Ed. 449.

20 "The reach and consequence of the contention repels its acceptance. 
hypothesis the extra-state demand is assured, there can be no diminution of interstate commerce and therefore no regulation thereof. Taxation having undue economic extraterritorial effect has been held unconstitutional under the commerce clause even though the results of sustaining the tax would have been to drive the taxpayer from local business within the state to the consequent increase of interstate commerce through sales from without the state.21 Whether, therefore, the taxes now under consideration should have been held unconstitutional under the commerce clause depends wholly upon whether their effect on extra-state interests can wisely be regarded as excessive. While the Supreme Court opinions do not analyze the issue as realistically as might be desired, its judgments must have been influenced by the practicalities, and it behooves us, therefore, to seek for the reasons why those judgments may be thought wise.

Some weight may be attached to the fact that the taxes were imposed prior to transportation and therefore were formally within

If the possibility, or indeed certainty, of exportation of a product or article from a state determines it to be in interstate commerce before the commencement of its movement from the state, it would seem to follow that it is in such commerce from the instant of its growth or production, and in the case of coals, as they lie in the ground. The result would be curious. It would nationalize all industries, it would nationalize and withdraw from state jurisdiction and deliver to federal commercial control the fruits of California and the South, the wheat of the West and its meats, the cotton of the South, the shoes of Massachusetts and the woolen industries of other states at the very inception of their production or growth, that is, the fruits unpicked, the cotton and wheat ungathered, hides and flesh of catle yet 'on the hoof', wool yet unshorn, and coal yet unmined because they are in varying percentages destined for and surely to be exported to states other than those of their production". 43 Sup. Ct. Rep. 83, 86.

This unwarranted apprehension neglects the peculiar situation of Pennsylvania anthracite which underlay the opposition to the Pennsylvania tax. That peculiar situation was curtly dismissed from consideration by saying:

"The contention that the tax is a regulation of interstate commerce seems to be based somewhat upon the declaration of the Governor of the state of its effect upon consumers in other states. We are unable to discern in the fact any materiality or pertinency, nor in the fact that Pennsylvania has a monopoly (if we may use the word) of the coal. Whether any statute or action of a state impinges upon interstate commerce depends upon the statute or action, not upon what is said about it or the motive which impclled it, and $a$ tax upon articles in one state that are destined for use in another state cannot be called a regulation of interstate commerce wliether imposed in the certainty of a return from a monopoly existing, or in the doubt or chances because of competition. The action of the state as a regulation of interstate commerce does not depend upon the degree of interference; it is illegal in any degree." Ibid.

21 Looney v. Crane Co. (1917) 245 U. S. 178, 62 L. Ed. 230, 38 Sup. Ct. Rep. 85; International Paper Co. v. Massachusetts (1918) 246 U. S. 135, 62 L. Ed. 624; 38 Sup. Ct. Rep. 292. 
an approved class. Opponents of taxes nominally and normally proper have the burden of proof in showing that substance demands a disregard of established technical categories. Adherence to formal categories facilitates the dispatch of judicial business and generates the generality which is one of the recognized aims of law. Departures because of substance should make out a clear case of substantial merit in the individual imstance and should in addition follow or help to make some workable line of demarcation. Judicial condemnation of the taxes under review would invite further complaints that would make it exceedingly difficult to draw the line. A case of complete monopoly and no local consumption owould seldom, if ever, appear. Degrees of monopoly will vary from commodity to commodity, and consumption ratios will change from year to year. It is not surprising that a court shrinks from zig-zagging through a trackless bog. Moreover, the complaint of discrimination against extra-state consumers is not so strong in substance as it sounds. At most there is in the aggregate a greater burden on those without the gates than on those within. The burden is proportional among individual consumers according to the quantities respectively consumed. A part of the complaint against Pennsylvania is more properly chargeable against Nature. A state with natural resources bears added costs of government due to the process of extracting them. It is fairly entitled to impose a charge upon that process sufficient to cover those costs and to yield something of a surplus, even if the extracted products go mainly to the mills and homes of other states. With some reason it may be thought that all that may wisely be demanded from the silence of the commerce clause is that the Supreme Court be astute to discover any device whereby the taxing state relieves domestic consumption or confers on it any direct or indirect bounty so that ton by ton the extra-state consumer contributes more to a covetous treasury than does the home consumer whom that treasury more directly serves. Even such devices may more readily be frustrated by invoking the privileges-and-immunities clause of Article IV and the equal-protection clause of the Fourteenth Amendment. These clauses may be brought into play by the simple judgment that a discrimination is unrcasonable without imdulging in the elaborate technicalities incident to the application of the commerce clause. In the instant cases the court considered the equal-protection issue and found that the state had not sufficiently offended to justify judicial intervention. We may accept this condonation as wise judicial statesmanship and still retain the impression that Pennsylvania would prove herself a worthier com- 
monwealth in the sisterhood of states by refraining from special tolls on anthracite and contenting herself with a non-discriminating tax on the net income from all enterprise within her borders.

Thomas Reed Powell.

University of California,

Berkeley, California. 